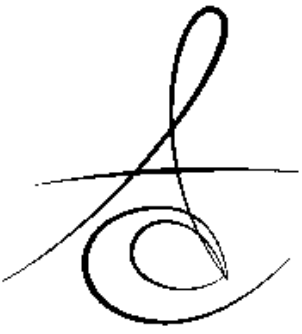

Arş. Gör. Dt. Özge ŞENTÜRK*

\section{CURRENT APPROACHES FOR TOOTH AGENESIS: A REVIEW}

DIŞ EKSIKLIĞINDE GÜNCEL YAKLAŞIMLAR: DERLEME

\author{
Dr. Öğr. Üyesi Kadriye Görkem ULU GÜZEL*
}

Makale Kodu/Article code: 3126

Makale Gönderilme tarihi: 10.11.2016

Kabul Tarihi: 29.12.2016

\section{ABSTRACT}

Hypodontia is defined as the congenital deficiency of one or more teeth and is one of the most common dental anomalies in humans. Multifactorial etiology can include environmental factors as well, since a combination of environmental and genetic factors might contribute to the occurrence of dental agenesis. Patient with missing teeth; reduced masticatory ability, inarticulate pronunciation may encounter esthetics and periodontal problems. Tooth agenesis definition, etiology, genes that cause tooth agenesis and treatment of tooth agenesis is mentioned in this review. Nowadays, many genes which play role in tooth development reported to be a potential candidate gene in tooth agenesis. Functional changes seen in genes which play role in tooth agenesis are mentioned that there may be a relationship with the development of cancer and tooth agenesis may be a significant marker for cancer.

Key Words: Hypodontia, prevalence, neoplasms

\section{öz}

Hipodonti, bir veya daha fazla dişin konjenital eksikliği olarak tanımlanır ve insanlarda en sık görülen dental anomalilerden biridir. Genetik faktörlerin yanısıra çevresel faktörler veya bunların kombinasyonu diş eksikliklerinin görülmesine sebep olabilmektedir. Eksik dişlere sahip hastalar; azalmış çiğneme yeteneği, telaffuzun anlaşılamaması, estetik ve periodontal problemlerle karşılaşabilmektedir. Bu derlemede konjenital diş eksikliği tanımı, etiyolojisi, diş eksikliğine sebep olan genler ve tedavisinden bahsedilmektedir. Günümüzde, diş gelişiminde rol alan birçok genin, diş eksikliğinde de potansiyel aday genler oldukları bildirilmektedir. Diş eksikliğinde rol alan genlerde görülen fonksiyonel değişikliklerin kanser gelişimiyle bir ilişkisi olabileceğinden ve diş eksikliğinin kanser için belirleyici bir marker olabileceğinden bahsedilmektedir. Anahtar Sözcükler: Hipodonti, prevalans, tümörler

\section{INTRODUCTION}

Tooth agenesis is defined developmental deficiencies of one or more decidious or permanent teeth except third molars. ${ }^{1}$

Tooth agenesis is the term most frequently used when describing the phenomenon of congenitally missing teeth in general. Many other terms appear in the literature to describe less number of teeth (oligodontia, anodontia, aplasia of teeth, congenitally missing teeth, absence of teeth, agenesis of teeth and lack of teeth). The term hypodontia is used in a narrow sense when the number of missing teeth is one or a few except third molars oligodontia is defined as missing a large number of teeth six or more than six teeth except third molars. Anodontia is an extreme case, denoting complete absence of teeth. ${ }^{2}$

\section{Prevalence}

While the most frequently missing tooth is third molar, except third molars the prevalence of tooth agenesis varies according to population. ${ }^{2}$

\footnotetext{
${ }^{*}$ Adnan Menderes Üniversitesi, Diş Hekimliği Fakültesi, Pedodonti AD, Aydın.
} 
In many studies on the prevalence of tooth agenesis, differences were observed between populations, continents and countries. Ethnic differences in the prevalence of tooth agenesis is outstanding. ${ }^{3}$ The prevalance of permanent tooth agenesis were found to be between studies in Asia continent \%1.4-\%9.4, ${ }^{4}$ in European studies $\% 4.5-\% 11.3,5,6$ in the United States studies $\% 3.5-\% 3.8^{3,4}$ studies in the Middle East \%0.3-\%6.2. ${ }^{6,7}$

In Europe, the United States, Asia and Middle East studies, the most frequently missing teeth were found maxillary lateral incisors and mandibular second premolars. ${ }^{4,7-9}$

The most common dental anomalies in Turkish population is said to be hypodontia. ${ }^{10}$ In Turkey, studies showed that the frequency of hypodontia were found between $\% 1.77-\% 21.6,{ }^{11,12}$ the prevalence of oligodontia were found to be between \%0.13$\% 0.3 .^{10,13}$ The most commonly missing teeth were found to be maxillary lateral incisors and followed by mandibular second premolars. ${ }^{10}$ The prevalence of missing maxillary lateral incisors were found between $\% 1.74-\% 46.5^{10,13}$ and the prevalence of missing mandibular second premolars were found between $\% 0.57-\% 38.8 .{ }^{11,14}$ The prevalence of bilateral missing maxillary lateral incisors were found between \%72$\% 84 .{ }^{10,15}$ The prevalence of tooth agenesis in females were more common than males and the prevalence in females were found to be between $\% 0.50-\% 8.9$, in males have shown to be between $\% 0.17-\% 6.4{ }^{14-16}$

\section{Etiology}

Altough there are many studies on tooth development, the etiology of tooth agenesis is not fully understood. ${ }^{17-19}$

Recent studies shows that tooth agenesis affected by a multifactorial etiology like gen functions, environmental factors and tooth development timing. Tooth agenesis might be familial or sporadic, associated with the syndrome or non-syndromic. ${ }^{20}$

\section{Environmental Factors}

Such as tooth agenesis is mostly due to genetic factors, environmental factors are also effective. Infection, trauma, traumatic extraction of primary teeth is stated that the major environmental factors. ${ }^{21}$

In many studies; allergy, using digoxin, chemotherapy, disease observed in pregnancy, environmental factors such as birth weigth might have an affect on the prevalence of hypodontia. ${ }^{22-26}$

\section{Genetic Factors}

Tooth agenesis is a heterogeneous condition as genetic and phenotypic. So far, more than 200 genes were identified in tooth development. ${ }^{27}$ Transcription (constituting DNA nucleotide sequence of a process of copying the mRNA sequence by RNA polymerase enzyme) factors, growth factors, growth factor receptors, cytokines, encoding extracellular matrix molecules have been shown to be expressed in tooth development of many gene family. ${ }^{28}$

Genetic plays a crucial role in tooth agenesis, as confirmed in studies on twins. ${ }^{6}$ All previous studies in monozygotic and dizygotic twins conducted hundreds of genes that regulate the shape and size of the teeth is genetically determined. ${ }^{29-31}$ In a Sweden family study, tooth agenesis has been reported to be inherited. In this study, the majority of cases seen familial hypodontia autosomal dominant deficiency has been shown. ${ }^{4}$

Recently it has been identified many mutations associated with tooth agenesis. First genes identified in tooth agenesis were reported to be PAX-9 (paired box 9) and MSX-1 (muscle segment homeobox 1). ${ }^{32,33}$

Many different mutations in genes such as MSX-1 and PAX-9 might cause tooth agenesis. It was reported that MSX-1 and PAX-9 play a significant role in mediating direct epithelial-mesenchymal interactions during in the early stages of tooth development especially bud and cap stages. ${ }^{34}$

Mice with the gene that causes the tooth agenesis show similar phenotypes like MSX-1, PAX-9 in humans. In addition, mice models shows that genes such as Lef gene might cause tooth agenesis. ${ }^{35}$

Except PAX-9 and MSX-1 genes, Lammi et al. ${ }^{27}$ have found that AXIN-2 (axis inhibition protein 2) and WNT10A (Wingless-Type family, member 10A) genes is also responsible for tooth development and these genes mutations cause to be tooth agenesis in 2004 . This modified gene nucleotide changes in the protein structure or protein interaction may result in incorrect structural proteins are mentioned. These cells and organs that need the function of the proteins causes one or more missing teeth not to be working properly. ${ }^{36}$ Furthermore, AXIN-2 mutations are associated with familial oligodontia and susceptibility to colorectal cancer. ${ }^{27}$

PAX-9 and MSX-1 methylation was found to be associated with cancer, but the relationship between

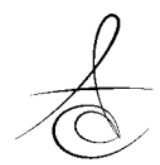


this situation could not be fully described with tooth agenesis. ${ }^{37}$ Posttranscriptional activity differences in these genes are reported to be caused dentoalveolar defects. $^{38}$ In studies a potential regulatory point functional relationship between MSX-1 and PAX-9 during tooth development has been identified. Such interactions can affect the development phase of the dental organ directly on DNA or by causing on their posttranscriptional activity changes and it is thought to MSX-1 and PAX-9's combined reduction of gene dosage may increase oligodontia prevalence. ${ }^{39,40}$

Prager et al. ${ }^{41}$ reported that PAX-9, AXIN-2 and MSX-1 genes are associated with non-syndromic tooth agenesis; EDA (Ectodysplasin A), EDAR (Ectodysplasin $A$ receptor), EDARADD (EDAR associated death domain), IRF-6 (Interferon regulatory factor 6), MSX1, NEMO (NF-Kappa-B Essential Modulator), P63 (Tumor protein P63), PITX-2 (Paired like homeodomain 2) and SHH (Sonic hedgehog) genes are associated with syndromic tooth agenesis.

\section{Tooth Agenesis and Cancer Relationship}

Studies in recent 10 years is mentioned there might be a marker for cancer predictor of tooth agenesis. ${ }^{42-46}$ (Table 1)

Table 1. Hypodontia patients with different tumors

\begin{tabular}{|l|l|}
\hline THE TYPE OF CANCER & GENE RESPONSIBLE \\
\hline Breast Cancer & AXIN2 \\
\hline Colorectal Cancer & AXIN2 \\
\hline Hodgkin Lenfoma & TP63 \\
\hline Over Cancer & BRCA1 \\
\hline Pancreas Cancer & AXIN2 \\
\hline
\end{tabular}

The first family of tooth agenesis with cancer was seen as a family with autosomal dominant oligodontia. The majority of the affected family member was found to be missing more than eight teeth; permanent molars, premolars, mandibular incisors, maxillary lateral incisors and colorectal neoplasia was seen in eight people in this family. If normal dentition has been observed that family members have to be seen any neoplasia. ${ }^{27}$

In another study it has been reported to be a more complex pedigrees. In family history; oligodontia, rare eyebrows, thin hair, colon polyps, early colon cancer and breast cancer were identified. At least six teeth of these patients were reported to be missing. ${ }^{45}$ In patients with familial adenomatous polyps were observed tooth agenesis. A 39 year old patient with 100 units of polyps was found to be some teeth are missing. ${ }^{43}$ In an epidemiological study, half of women with ovarian cancer were observed missing teeth; so it can be considered that the women with tooth agenesis for the estimates reduce the risk of ovarian cancer. ${ }^{46}$

Although studies suggest an association between tumorigenesis and tooth agenesis, there are still some weak spots, cases may not reflect the population as a whole. In addition to environmental factors, individual differences in the development of the disease has a great impact. Studies have shown a small sample size. ${ }^{46}$

Dental Anomalies Associated with Tooth

\section{Agenesis}

There are many dental anomalies associated with tooth agenesis. These are; late tooth formation and eruption, microdontia, conical crown shape, prolonged retention of primary teeth (persistence), impacted teeth (especially maxillary canines), ectopic eruption, malposition of the teeth, infraposition of primary molars, short-rooted teeth, molar taurodontism, rotations on premolars or/and maxillary lateral incisors, enamel hypoplasia and hypocalcification. ${ }^{47}$

\section{Syndromic Tooth Agenesis}

Tooth agenesis can be a primary feature of many syndromes affecting several other ectodermal organs at the same time. A constantly updated catalog of human genes, OMIM (Online Mendelien Inheritance in Man), that examined the characteristics of human genes and genetic disorders in terms of genephenotype relationship. In this catalog, more than 60 syndromes listed related tooth agenesis. ${ }^{48}$

Agenesis of maxillary central incisors, canines, second molars and molars are rarely seen. Tooth agenesis of these teeth is often associated with significant syndromes. ${ }^{4,49-57}$ (Table 2)

Table 2. Other syndromes associated with tooth agenesis and related genes

\begin{tabular}{|c|c|}
\hline NAME OF SYNDROME & GENE RESPONSIBLE \\
\hline Witkop Syndrome & $\mathrm{MSX}^{49,50}$ \\
\hline Rieger Syndrome & PITX $^{51}$ \\
\hline Van der Woude Syndrome & IRF6 $^{52}$ \\
\hline Wolf-Hirschhorn Syndrome & $4 p$ deletions $s^{53}$ \\
\hline Inkontinentia Pigmenti & $\mathrm{NEMO}^{54}$ \\
\hline EEC3 Syndrome & $\mathrm{p} 63^{55}$ \\
\hline AEC Syndrome & $p 63^{55}$ \\
\hline Seckel Syndrome & ATR $^{56}$ \\
\hline Oral-Facial-Digital Syndrome & CXORF5 $^{57}$ \\
\hline
\end{tabular}




\section{Treatment of Tooth Agenesis}

There are clinical implications of tooth agenesis affecting the physical and emotional state of the person. Treatment is expensive and comprehensive and requires a multidisciplinary work. ${ }^{18} \mathrm{~A}$ treatment including oral and maxillofacial surgeon, pediatric dentist, prosthodontist, orthodontist, specialists in restorative dentistry, dental nurses, speech therapists, psychologists should be considered. ${ }^{6,18,58-60}$

Considering the risk factors about tooth agenesis and early detection of missing teeth number, the number and size of the teeth in both two dental arch is important to manage the treatment plan. ${ }^{6,17,61}$ Determining the type of malocclusion and facial profile, final treatment plan plays a big role. ${ }^{6}$ Other therapeutic challenge is the treatment in growing young patients. ${ }^{18,62}$ Treatment should begin during adolescence is indicated. ${ }^{18,61,62}$

\section{Treatment Methods in Agenesis of Primary Teeth}

Agenesis of primary teeth rarely seen. During this period, for the treatment of hypodontia or anodontia, removable prosthesis can be used to provide in terms of function and achieve an esthetic appearance. Using removable prothesis would have avoided difficulty with speech and eating problems, and ensure that children are psychologically happy. ${ }^{63}$

Lexner and Almer, ${ }^{64}$ in a study conducted in ectodermal dysplasia patients, they have reported success in terms of using removable prothesis for patients, parents and dentists. They have said that young patients have better adaptation to the prothesis.

\section{Agenesis}

Treatment Methods in Permanent Tooth

Treatment of permanent tooth agenesis is indicated as a treatment should be evaluated multidisciplinary. ${ }^{65-69}$

If tooth agenesis is on anterior region, esthetics problems may occur. There is no formal procedure defined for the treatment of these patients. The treatment should be planned according to the severity of tooth agenesis, occlusion, soft tissue and skeletal pattern, facial profile, the number of remaining teeth-shape-color, location of the missing tooth, alveolar bone quantity, oral hygiene, patient care, expectations of the patient's from treatment, communication between patient-dentist and the cost of the treatment. ${ }^{70}$ Closing space or according to the requirements of the protection of the space; orthodontic treatment, restorative treatment (crowns, bridges), autotransplantation, different treatment options such implants can be done. ${ }^{70,71}$

If maxillary lateral incisor is missing in mixed dentition, with early extraction of primary incisors and canines; maxillary canines rather than be allowed to erupt instead of maxillary lateral incisors. Its purpose is to protect the alveolar bone for the implant to be placed in the future. ${ }^{6,65,66}$

Guidance eruption can also be use in treatment of tooth agenesis. The purpose of the guidance eruption is, to provide the teeth take place in dental arch in a natural way without using any appliances. Agenesis of maxillary lateral incsiors, closing space with guidance eruption aims maxillary canines eruption instead of maxillary lateral incisors and class 2 occlusion. For this purpose, maxillary first and second primary molars should to be abrade from both mesial and distal. Abrasion operations is made six months ago from maxillary first premolars eruption. Success depends on the order of the teeth eruption and direction. In agenesis of maxillary and mandibular premolars, if the space of the maxillary and mandibular molars' closure with guidance eruption; abrading maxillary and mandibular molars from distal, primary second molars both mesial and distal, early extraction of maxillary and mandibular primary first and second molars, guidance eruption can be done. ${ }^{72,73}$

Another treatment method is autotransplantation. $^{74}$ Referring prosthetic, transplantation is thought to be a better choice than the implant; osseointegrated implants placing to the growing alveolar bone is not correct. Successful autotransplantation of teeth, depending on the physiological stimulation of the periodontal ligament provides stability of alveolar bone volume. ${ }^{6}$ It is stated that children should be delayed until completion of adolescence implant treatment. ${ }^{6,75}$

Autotransplantation of premolars may be recommended in patients with multiple agenesis of maxillary incisors. In growing children transplated teeth can induce alveolar ridge growth and development and also it may be a permanent solution for agenesis of teeth. ${ }^{76}$ 
In studies the long-term success of autotransplantation of premolars were reported to be between $\% 70-\% 98 .{ }^{76,77}$

In a study conducted by Dueled et al. ${ }^{78}$ two groups of patients having maxillary lateral agenesis were compared. One group had been treated with space opening prior to locating implants. The other group had been treated with conventional fixed bridges or other prosthetic appliances. Both esthetic and functional both in terms of patient satisfaction, the success rate of patients treated with the implant were higher. (\%83-\%92). In patients treated with fixed prosthesis was found between the rate of \%41$\% 47$.

Robertsson and Mohlin, ${ }^{75}$ have closed space in a group of patients with orthodontic treatment in agenesis of maxillary lateral incisors and they have shaped canine like lateral incisor. Other groups of patients they have placed fixed bridges by opening space. Betweeen the two groups of patients, satisfaction of the patients that treated with closing space were higher than those of patients who had bridges. Plaque accumulation and gingivitis in these two groups in terms of a comparison is made and the patients who have closed space was seen with more satisfying results.

In the literature, the survival rate of the implants is observed studies on implant treatment in patients with the hypodontia vary from \%35.7 up to \%98.7. ${ }^{78,79}$ About that, the most important risk factor is implant localization. The loss of implants in maxilla have seen more than mandibula because of the bone density. The patients with oligodontia, anodontia and ectodermal dysplasia in a comparison to healty patients was found more implant loss due to lower bone mass. ${ }^{79}$ Guckes et al. ${ }^{80}$ reported that patients with ectodermal dysplasia is not a contraindication for implant treatment.

Some studies have used the oral health related quality of life test to assess patient satisfaction after implant treatment and the results found that particularly high in patients with oligodontia. ${ }^{81}$

\section{CONCLUSION}

Tooth agenesis is a complex problem for dentists worldwide. In studies; tooth agenesis classification, prevalence, etiology, associated anomalies, clinical effects, treatment options are discussed. Also in recent years, based on current research and clinical observation, it has been suggested that genetic factors affect both tooth development and tumor formation commonly. Tooth agenesis has shown to be a potential marker for the development of future cancer in studies. It is stated that prospective studies are needed to fully elucidate the mechanism. The first point about tooth agenesis in the future, dentists care not only the state of the maxillofacial region, they will care about the whole body health generally.

Özge Şentürk: ORCID ID: 0000-0002-0528-1660

K.Görkem Ulu Güzel: ORCID ID: 0000-0002-3129-849

\section{REFERENCES}

1. Bailleul-Forestier I, Molla M, Verloes A, Berdal A. The genetic basis of inherited anomalies of the teeth. Part 1: clinical and molecular aspects of non-syndromic dental disorders. Eur J Med Genet 2008; 51: 273-91.

2. Arte S. Phenotypic and genotypic features of familial hypodontia. Department of Pedodontics and Orthodontics Helsinki, Finland University of Helsinki 2001: 12-4.

3. Polder BJ, Van't Hof MA, Van der Linden FP, Kuijpers-Jagtman AM. A meta-analysis of the prevalence of dental agenesis of permanent teeth. Community Dent Oral Epidemiol 2004; 32: 217-26.

4. Shimizu T, Maeda T. Prevalence and genetic basis of tooth agenesis. Jpn Dentl Sci Rev 2009; 45: 528.

5. Nordgarden H, Jensen JL, Storhaug K. Reported prevalence of congenitally missing teeth in two Norwegian counties. Community Dent Health 2002; 19: 258-61.

6. Fekonja A. Hypodontia in orthodontically treated children. Eur J Orthod 2005; 27: 457-60.

7. Abed Al Jawad FH, Al Yafei H, Al Sheeb M, Al Emadi $B$, Al Hashimi N. Hypodontia prevalance and distribution pattern in a group of Qatari orthodontic and pediatric patients: A retrospective study. Eur J Dent 2015; 9: 267-71.

8. Hashim HA, Al-Said S. The prevalance and distribution of hypodontia in a sample of Qatari patients. J Orthod Sci 2016; 5: 1-6.9. Hassan DA, Abuaffan $\mathrm{AH}$, Hashim $\mathrm{HA}$. Prevalence of hypodontia in a sample of Sudanese orthodontic patients. J Orthod Sci. 2014; 3: 63-7. 
9. Hassan DA, Abuaffan AH, Hashim HA. Prevalance of hypodontia in a sample of Sudanese orthodontic patients. J Orthod Sci 2014; 3: 63-7.

10. Altuğ A, Erdem D. Prevalence and distribution of dental anomalies in orthodontic patients. Am J Orthod Dentofacial Orthop 2007; 131: 510-514.

11. Aren G, Güven Y, Tolgay CG, Özcan İ, Bayar ÖF et al. The prevalence of dental anomalies in a Turkish population. J Istanbul Univ Fac Dent 2015; 49: 238.

12. Uslu O, Akcam MO, Evirgen S, Cebeci İ. Prevalence of dental anomalies in various malocclusions. Am J Orthod Dentofacial Orthop 2007; 135: 328-35.

13. Celikoglu M, Kazanci F, Miloglu O, Oztek O, Kamak $\mathrm{H}$, Ceylan I. Frequency and characteristics of tooth agenesis among an orthodontic patient population. Med Oral Patol Oral Cir Bucal 2010, 15: 797-801.

14. Ezirganlı Ş, Köşger H, Özer K, Kırtay M, Ün E. Prevalence Of CongenItally Missing Second Premolars. Cumhuriyet Dent J 2010, 13: 48-51.

15. Kazanci F, Celikoglu M, Miloglu O, Ceylan I, Karmak $H$. Frequency and distribution of developmental anomalies in the permanent teeth of a Turkish orthodontic patient population. J Dent Sci 2011; 6: 82-9.

16. Candan Ü, Kıpçak Ö, Evcil MS. Prevalance of congenitaly missing permanent teeth in Aegean region children. Atatürk Univ Fac Dent J. 2014; 24 : 349-52.

17. Goya HA, Tanaka S, Maeda T, Akimoto Y. An orthopantomographic study of hypodontia in permanent teeth of Japanese pediatric patients. J Oral Sci 2008; 50: 143-50.

18. Behr M, Proff P, Leitzmann M, Pretzel M, Handel G, Schmalz G. Survey of congenitally missing teeth in orthodontic patients in Eastern Bavaria. Eur J Orthod 2010; 5: 32-3.

19. Lyngstadaas SP, Nordbo H, Gedde-Dahl T Jr, Thrane PS. On the genetics of hypodontia and microdontia: Synergism or allelism of major genes in a family with six affected members. J Med Genet 1996; 33: 137-42.

20. Cobourne MT. Familial human hypodontia is it all in the genes? Br Dent J 2007; 203: 203-8.

21.AIShahrani I, Togoo RA, AlQarni MA. A Review of Hypodontia: Classification, Prevalence, Etiology, Associated Anomalies, Clinical Implications and Treatment Options. World J Dent 2013; 4: 11725.
22. Marec-Berard $P$, Azzi D, Chaux-Bodard AG, Lagrange $\mathrm{H}$, Gourmet $\mathrm{R}$, Bergeron $\mathrm{C}$. Long-term effects of chemotherapy on dental status in children treated for nephroblastoma. Pediatr Hematol Oncol 2005; 22: 581-8.

23. Keller JM, Huet-Hudson YM, Leamy LJ. Qualitative effects of dioxin on molars vary among inbred mouse strains. Arch Oral Biol 2007; 52: 450-4.

24. Yamaguchi T, Tomoyasu $Y$, Nakadate $T$, Oguchi $K$, Maki K. Allergy as a possible predisposing factor for hypodontia. Eur J Orthod 2008; 30: 641- 4.

25. Parkin N, Elcock C, Smith RN, Griffin RC, Brook $\mathrm{AH}$. The aetiology of hypodontia: the prevalence, severity and location of hypodontia within families. Arch Oral Biol 2009; 54: 52-6.

26. Pedersen LB, Clausen N, Schrøder H, Schmidt M, Poulsen S. Microdontia and hypodontia of premolars and permanent molars in childhood cancer survivors after chemotherapy. Int J Paediatr Dent 2012; 22: 239-43.

27. Lammi L, Arte S, Somer M, Jarvinen H, Paivi L, Thesleff $I$ et al. Mutations in AXIN2 cause familial tooth agenesis and predispose to colorectal cancer. Am J Hum Genet 2004; 74: 1043-50.

28. Kantaputra P, Sripathomsawat W. WNT10A and isolated hypodontia. Am J Med Genet 2011; 155: 1119-22.

29. Brook AH, Elcock C, Aggarwal M, Lath DL, Russel JM, Patel PI, Smith RN. Tooth dimensions in hypodontia with a known PAX-9 mutation. Arch Oral Biol 2009; 54: 57-62.

30. Townsend G, Hughes T, Luciano M, Bockmann M, Brook $A$. Genetic and environmental influences on human dental variation: A critical evaluation of studies involving twins. Arch Oral Biol 2009; 54: 45-51.

31. Townsend G, Alvesalo L, Brook A. Variation in the Human Dentition: Some Past Advances and Future Opportunities. J Dent Res 2008; 87: 802-5.

32. Boeira $\mathrm{Br} \mathrm{Jr}$, Echeverrıgaray $\mathrm{S}$. Novel missense mutation in PAX9 gene associated with familial tooth agenesis. J Oral Pathol Med 2013; 42: 99105.

33. Mostowska A, Zadurska M, Rakowska A, Lianeri M, Jagodzinski PP. Novel PAX9 mutation associated with syndromic tooth agenesis. Eur J Oral Sci 2013; 121: 403-11.

34. Mitsiadis TA, Luder HU. Genetic basis for tooth malformations: from mice to men and back again. Clin Genet 2011; 80: 319-29. 
35. Shimizu T, Morita W, Maeda T. Genetic mapping of agenesis of the third molars in mice. Biochem Genet 2013; 51: 728-36.

36. Henningsen $E$, Svendsen MT, Lildballe DL, Jensen PK. A novel mutation in the EDAR gene causes severe autosomal recessive hypohidrotic ectodermal dysplasia. Am J Med Genet 2014; 164 : 2059-61.

37. Rauch T, Li H, Wu X, Pfeifer GP. Mira-assisted microarray analysis, a new technology for the determination of DNA methylation patterns, identi es frequent methylation of homeodomain containing genes in lung cancer cells. Cancer Res 2006; 66: 7939-47.

38. Coudert AE, Pibouin L, Vi-Fane B, Thomas BL, Macdougall $M$, Choudhury A. Expression and regulation of the Msx1 natural antisense transcript during development. Nucleic Acids Res 2005; 33: 5208-18.

39. Ogawa T, Kapadia H, Wang B, D'Souza RN. Studies on Pax9-Msx1 protein interactions. Arch Oral Biol 2005; 50: 141-145.

40. Nakatomi M, Wang XP, Key D, Lund JJ, TurbeDoan A, Kist R. Genetic interactions between Pax9 and Msx1 regulate lip development and several stages of tooth morphogenesis. Dev Biol 2010; 340: 438-49.

41. Prager TM, Finke C, Miethke RR. Dental findings in patients with ectodermal dysplasia. J Orofac Orthop 2006; 67: 347-55.

42. Vogelaar IP, Figueiredo J, van Rooij IA. Identification of germline mutations in the cancer predisposing gene $\mathrm{CDH} 1$ in patients with orofacial clefts. Hum Mol Genet 2013; 22: 919-26.

43. Lejeune $S$, Guillemot F, Triboulet JP. Low frequency of AXIN2 mutations and high frequency of MUTYH mutations in patients with multiple polyposis. Hum Mutat 2006; 27: 1064.

44. Lindor NM, Win AK, Gallinger S. Colorectal cancer and self-reported tooth agenesis. Hered Cancer Clin Pract 2014; 12: 7.

45. Marvin ML, Mazzoni SM, Herron CM, Edwards S, Gruber SB, Petty EM. AXIN2-associated autosomal dominant ectodermal dysplasia and neoplastic syndrome. Am J Med Genet 2011; 155: 898-902.

46. Bonds J, Pollan-White S, Xiang L, Mues G, D'Souza $R$. Is there a link between ovarian cancer and tooth agenesis. Eur J Med Genet 2014; 57: 23539.
47. Cobourne MT, Sharpe PT. Tooth and jaw: molecular mechanisms of patterning in the first branchial arch. Arch Oral Biol 2003; 48: 1-14.

48. Ada H, Alan FS, Joanna SA, Carol AB, Victor AM. A knowledgebase of human genes and genetic disorders. OMIM 2005; 33: 514-7.

49. Bural C, Oztas E, Ozturk S, Bayraktar G. Multidisciplinary treatment of nonsyndromic oligodontia. Eur J Dent 2012; 6: 218-26.

50. Mikulás K, Kivovics P, Nagy G, Márton K, Madléna M. Complex oral rehabilitation of a patient with Witkop's syndrome: an interdisciplinary approach. Oral health Dent Manage Black Sea Ctries. 2008; 7: 56-60.

51. Lines MA, Kozlowski K, Walter MA. Molecular genetics of Axenfeld-Rieger malformations. Hum Mol Genet 2002; 11: 1177-87.

52. Hersh JH, Verdi GD. Natal teeth in monozygotic twins with Van der Woude syndrome, Cleft Palate Craniofac 1992; 29: 279-81.

53. South ST, Whitby H, Battaglia A, Carey JC, Brothman AR. Comprehensive analysis of WolfHirschhorn syndrome using array CGH indicates a high prevalence of translocations. Eur J Hum Genet 2008; 16: 45-52.

54. Hacker $\mathrm{H}$, Karin M. Regulation and function of IKK and IKK related kinases. Sci Stke 2006; 357: 10-3.

55. Monti P, Russo D, Bocciardi R, Foggetti G, Menichini $P$, Divizia MT et al. Eec and adult associated TP63 mutations exhibit functional heterogeneity toward P63 responsive sequences. Hum Mutat 2013; 34: 894-904.

56. ODriscoll M, RuizPerez VL, Woods CG, Jeggo PA, Goodship JA. A splicing mutation affecting expression of ataxia telangiectasia and Rad3 related protein (ATR) results in Seckel syndrome. Nat Genet 2003; 33: 497-501.

57. Feather SA, Woolf AS, Donnai D, Malcom S, Winter RM. The oral-facial-digital syndrome type 1 (OFD1), a cause of polycystic kidney disease and associated malformations, maps to Xp22.2-Xp22.3. Hum Mol Genet 1997; 6: 1163-67.

58. Kim YH. Investigation of hypodontia as clinically related dental anomaly: Prevalence and characteristics. ISRN Dent 2011;246135: 0-6.

59. Wong AT, McMillan AS, McGrath C. Oral health related quality of life and severe hypodontia. J Oral Rehabil 2006; 33: 869-73.

60. Behr M, Driemel O, Mertins V, Gerlach T, Kolbeck C, Rohr N. Concepts for the treatment of 
adolescent patients with missing permanent teeth. Oral Maxillofac Surg 2008; 12: 49-60.

61. Nunn JH, Carter NE, Gillgrass TJ, Hobson RS, Jepson NJ, Meechan JG. The interdisciplinary management of hypodontia: Background and role of paediatric dentistry. Br Dent J 2003; 194: 24551.

62. Rossi E, Andreasen JO. Maxillary bone growth and implant positioning in a young patient: a case report. Int J Periodontics Restorative Dent 2003; 23: 113-9.

63. DS Gill, CS Barker. The multidisciplinary management of hypodontia: a team approach. $\mathrm{Br}$ Dentl J 2015; 218: 143-9.

64. Lexner MO, Almer L. Case series: Treatment considerations in $\mathrm{x}$-linked hypohidrotic ectodermal dysplasia. Eur Arch Paediatr Dent 2009; 10: 26-30.

65. Mattheeuws N, Demaut L, Martens G. Has hypodontia increased in Caucasians during the 20th century. A meta-analysis. Eur J Orthod 2004; 26: 99-103.

66. Kinzer GA, Kokich JrVO. Managing congenitally missing lateral incisors. Part III: Single-tooth implants. J Esthet Restor Dent 2005; 17: 202-10.

67. Hobson RS, Carter NE, Gillgrass TJ, Jepson NJ, Meechan JG, Nohl F et al. The interdisciplinary management of hypodontia: the relationship between an interdisciplinary team and the general dental practitioner. Br Dent J 2003; 194: 479-82.

68. Kokich VO, Kinzer GA, Janakiesvski J. Congenitally missing lateral incisors:Restorative replacement. Am J Orthod Dentofacial Orthop 2011; 139: 43545.

69. Zachrisson BU, Rosa M, Toreskog S. Congenitally missing maxillary lateral incisors: Canine substitution. Am J Orthod Dentofacial Orthop 2011; 139: 434-45.

70. Valle $A L$, Lorenzoni FC, Martins LM, Valle CVM, Henriques JFC, Almeida ALPF. A multidisciplinary approach for the management of hypodontia: Case report, J Appl Oral Sci 2011; 19: 544-8.

71. Al-Anezi SA. Orthodontic treatment for a patient with hypodontia involving the maxillary lateral incisors. Am J Orhtod Dentofacial Orthop 2011; 139: 690-7.

72. Park JH, Okadakage S, Sato Y, Akamatsu Y, Tai K.. Orthodontic treatment of a congenitally missing maxillary lateral incisor. J Esthet Restor Dent 2010; 22: 297-312.
73. Keski-Nisula $K$, Hernesniemi $R$, Heiskanen M, Keski-Nisula L, Varrela J. Orthodontic intervention in the early mixed dentition: A prospective, controlled study on effects of the eruption guidance appliance. Am J of Orthod Dentofacial Orthop 2008; 133: 254-60.

74. Chung $\mathrm{CJ}$, Han $\mathrm{JH}$, Kim KH. The pattern and prevalence of hypodontia in Koreans. Oral Dis 2008; 14: 620-5.

75. Robertsson S, Mohlin B. The congenitally missing upper lateral incisor. A retrospective study of orthodontic space closure versus restorative treatment. Eur J Orthod 2000; 22: 697-710.

76. Aslan BI, Ucuncu N, Dogan A. Long term follow-up of a patient with multiple congenitally missing teeth treated with autotransplantation and orthodontics. Angle Orthod 2010; 80: 396-404.

77. Oğuz HT , Üçüncü N . Ortodontide Otojen Diş Transplantasyonu Gazi Diş Hek Fak Derg 2007; 24: 63-9.

78. Dueled E, Gotfredsen K, Damsgaard MT, Hede B. Professional and patient-based evaluation of oral rehabilitation in patients with tooth agenesis. Clin Oral Implants Res 2009; 20: 729-36.

79. Pjetursson BE, Asgeirsson AG, Zwahlen M, Sailer I. Improvements in implant dentistry over the last decade: comparison of survival and complication rates in older and newer publications. Int J Oral Maxillofac Implants 2014; 29: 308-324.

80. Guckes AD, Scurria MS, King TS, McCarthy GR, Brahim JS. Prospective clinical trial of dental implants in persons with ectodermal dysplasia. J Prosthet Dent 2002; 88: 21-5.

81. Heuberer S, Dvorak G, Zauza K, Watzek G. The use of onplants and implants in children with severe oligodontia: a retrospective evaluation. Clin Oral Implants Res 2012; 23: 827-31.

\section{Yazışma Adresi}

Arş. Gör. Dt. Özge ŞENTÜRK

Adnan Menderes Üniversitesi Diş Hekimliği

Fakültesi Pedodonti Anabilim Dalı

Hasan Efendi mah. Aydın, Türkiye

Gsm: 05375282877

Tel: 02562133939

Fax: 02562151918

E-mail: ozgee_sntrk@hotmail.com 